\title{
Characterization of Thermophile Xylanase Produced by Anoxybacillus sp. Strain 3M in Submerged Fermentation Using Brewers' Spent Grain
}

\author{
Luís Alves ${ }^{1, *}$, Silvania A. Ladeira ${ }^{2}$ and Susana M. Paixão ${ }^{1, *}$
}

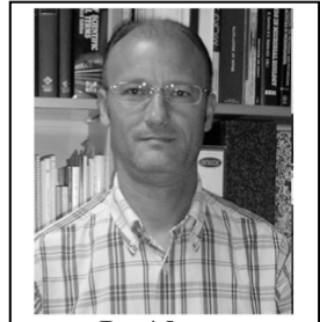

L. Alves

${ }^{1}$ LNEG - Laboratório Nacional de Energia e Geologia IP, Unidade de Bioenergia, Estrada do Paço do Lumiar, 22, 1649-038 Lisbon, Portugal; ${ }^{2}$ UENF - Universidade Estadual do Norte Fluminense Darcy Ribeiro, LTA - CCTA, Campos dos Goytacazes, RJ, Brazil

Abstract: The main goal of this study was the characterization of the extremophile xylanases produced by Anoxybacillus sp. strain 3M, a thermophilic bacterium isolated from terrestrial hot springs (temperature of $90^{\circ} \mathrm{C}$ ) samples collected on S. Miguel, Azores, Portugal. In this context, several batch fermentations using different agroindustrial wastes as inducer substrates (BSG - Brewers' spent grain, wheat straw, sug-

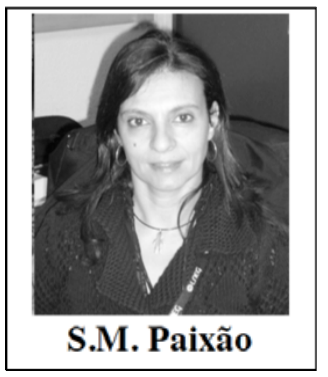

arcane bagasse, and corn cobs) were performed towards an optimal enzyme production. The results for xylanase production showed that the higher enzymatic levels were obtained in the growth medium containing $1 \%(w / v)$ BSG $\left(1.34 \mathrm{U} \mathrm{mL}^{-1}\right)$, indicating that the BSG was the best inducer substrate, but the xylanase activity was also observed when wheat straw $\left(1.33 \mathrm{U} \mathrm{mL}^{-1}\right)$, sugarcane bagasse $\left(0.80 \mathrm{U} \mathrm{mL}^{-1}\right)$, corn cobs $\left(0.30 \mathrm{U} \mathrm{mL}^{-1}\right)$ and commercial xylan $\left(0.21 \mathrm{U} \mathrm{mL}^{-1}\right)$ were used as inducers. The extracellular crude enzymatic extract produced by Anoxybacillus sp. 3M in optimized submerged fermentation with BSG, attaining a maximal xylanase activity of $1.41 \mathrm{U} \mathrm{mL}^{-1}$ (i.e. 5 -fold higher than with xylan), was further characterized for its optimal temperature and $\mathrm{pH}$ and stability. The highest enzyme activity was observed at a temperature of $60^{\circ} \mathrm{C}$ and $\mathrm{pH} 5.3$, but the enzyme retained $100 \%$ of its original activity after $96 \mathrm{~h}$ at $60^{\circ} \mathrm{C}$ and $\mathrm{pH} 7.0$ and it still maintained $46 \%$ activity after 28 days at the same conditions. At $60^{\circ} \mathrm{C}$, the enzyme also retained its activity for $\mathrm{pH}$ ranging from 7.0 to 10.5. In addition, a zymogram of native gel analysis of the different culture supernatants revealed the presence of an enzymatic complex with an apparent molecular weight ranging from 400-500 kDa. Further application of strain 3M enzymatic extract to commercial oat spelts xylan revealed the presence of xylose and xylooligosaccharides (XOS), mainly $\mathrm{X}_{2}$ and $\mathrm{X}_{3}$, in the hydrolyzates produced. So, the thermostable and alkalistable extracellular xylanases from Anoxybacillus sp. 3M are biocatalysts with high potential for the development of processes where lignocellulosics are converted to precursors for several biotechnological applications.

Keywords: Anoxybacillus sp. 3M, xylanase activity, enzyme production, thermostability, alkalistability, agro-industrial wastes.

\section{INTRODUCTION}

Xylan, the major component of hemicellulose complex of plant cell wall, is a heterogeneous polysaccharide with a linear backbone formed by $\beta$-1,4-D-xylopyranosides residues and its biodegradation requires the action of several enzymes. The hydrolysis products of xylans consist of monomers D-xylose and xylooligosaccharides (XOS) of different sizes [1-4]. The xylan breakdown involves, among other hemicellulases, endoxylanase (endo- $\beta-1,4-\mathrm{D}$-xylanase, EC 3.2.1.8), which cleaves internal links of the heteroxylan skeleton resulting in the reduction of the polymerization degree of the substrate, and $\beta$-xylosidase ( $\beta$-1,4-D-xylosidase, EC 3.2.1.37), which cleaves XOS to produce xylose.

Xylanases are found in terrestrial and marine bacteria, fungi, algae, protozoa, snails, crustaceans, insects and seeds of terrestrial plants. A search for new strains of microorganisms

*Address correspondence to these authors at the LNEG - Laboratório Nacional de Energia e Geologia IP, Unidade de Bioenergia, Estrada do Paço do Lumiar, 22, 1649-038 Lisbon, Portugal; Tel/Fax: +351 210924 600; E-mails: luis.alves@lneg.pt; susana.alves@lneg.pt producing xylanases with improved physiological characteristics in relation to temperature, $\mathrm{pH}$, and greater variety of substrate fermentation, resistance and adaptability to the toxicity of low-cost substrates is still needed, taking into account the existing great biodiversity [5].

Xylanases have a broad industrial employment such as in the food industry, textile and paper handling [6-9]. Thermostable xylanases themselves are good strategy as additives for bakery products in the stages of production and storage $[7,8]$, and they can also be used in paper production [10]. Xylanases facilitate the delignification of the pulp to produce high quality paper, thus contributing for a less use of bleaching agents containing chlorine, which are a serious problem of the ecological point of view [9]. The demand for industrial enzymes, particularly of microbial origin is ever increasing owing to their applications in a wide variety of processes [11]. Moreover, the discovery of thermostable and alkalistable enzymes is desirable in order to increase catalytic efficiency throughout industrial processes due to variable conditions and treatment temperatures. 